\title{
The Effectiveness of Cultural Deep Breathing against Blood Pressure Reduction
}

\author{
Agussalim $^{1 *}$, Muhammad Asikin ${ }^{2}$, I Takko Podding ${ }^{3}$, M.Nasir ${ }^{4}$, Abidin ${ }^{5}$, Edi Hasan ${ }^{6}$, Abd. Rahman ${ }^{7}$ \\ 1,2,3,4,5,6,7 Nursing Department, Parepare school of Nursing, Health Polytechnic of Makassar, Indonesia.
}

*Corresponding Author: Agussalim, Nursing Department, Parepare school of Nursing, Health Polytechnic of Makassar, Indonesia.

Received date: November 11, 2021; Accepted date: December 18, 2021; Published date: January 03, 2022

Citation: Agussalim, M Asikin, I Takko Podding, M. Nasir, Abidin, Edi Hasan, Abd. Rahman (2022). The Effectiveness of Cultural Deep Breathing against Blood Pressure Reduction. J. Addiction Research and Adolescent Behaviour. 5(1); DOI: 10.31579/2688-7517/033

Copyright: (C) 2022 Agussalim, This is an open access article distributed under the Creative Commons Attribution License, which permits unrestricted use, distribution, and reproduction in any medium, provided the original work is properly cited.

\begin{abstract}
Elderly is a process of disappearing in the ability of tissues to repair themselves or replace themselves and maintain their normal structure and function. This study aims to find out the effectiveness of deep breathing against decreased blood pressure in the elderly who have hypertension. The study used the one group pre-post test. The sample used as many as 13 participants. The study used Purposive Sampling techniques and the tool used to obtain the data. The study used a paired sample t-test with a significance value of $\alpha=0.05$. The results of this study showed that there was an effect of deep breathing on the decrease in blood pressure in the elderly who had hypertension on the first day and the third day with a value of $p=0.000<\alpha=0.05$. There is an effect of giving deep breathing to decrease blood pressure in elderly people who have hypertension on the 4th day and the sixth day with a value of $p=0.000<\alpha$ $=0.05$. There is an effect of giving deep breathing to the decrease in blood pressure in the elderly who have hypertension.
\end{abstract}

Keywords: cultural deep breathing; blood pressure; hypertension; elderly

\section{Introduction}

Elderly or aging (getting old) is a process of disappearing in the ability of tissues to repair themselves or replace themselves and maintain their normal structure and function so that it cannot be gradually against the cells damage (including infections) and repair damage that causes degenerative diseases e.g., hypertension, arteriosclerosis, diabetes mellitus and cancer (Nurrahmani, 2012, in Sulastri, 2015).

According to Jubaidi (2008) (In Sulastri, 2015) there are several physical changes in the elderly that can be a condition of the elderly stricken with disease, such as cardiovascular changes that decrease the elasticity of blood vessels, changes in respiration, namely decreased strength of respiratory muscles, as well as changes in hearing and changes in vision. There are several types of diseases that commonly afflict the elderly, including hypertension, diabetes mellitus, coronary diseases, stroke, cataracts, and so on. These kinds of health problems that often afflict the elderly are hypertension which can be causes of various other cardiovascular problems that are more serious.

Today the increase in welfare, especially in the field of health, is an important highlight. The onset of various diseases in the community has a great impact on their lives. One type of disease that continues to grow and increase is hypertension or known by ordinary people as High Blood Pressure. Changes in lifestyle and community needs are considered to have a great influence on the occurrence of hypertension. Hypertension itself can be monitored through blood pressure measurements. Hypertension is a persistent high blood pressure where the systolic pressure is above $140 \mathrm{mmHg}$ and the diastolic pressure is above $90 \mathrm{mmHg}$ (Smeltzer \& Bare, 2002 quoted from Kurniawan, 2014). Nearly 1 billion or quarters of the adult and elderly population have high blood pressure, and this number is likely to increase. In the elderly population, the number of people with high blood pressure is even more, experienced by more than half of the population of people over the age of 60 years. By 2025 it is estimated that people with high blood pressure reach almost 1.6 billion people in the world (Palmer, 2007 quoted in Hairitama, Rini, et al, 2011).

Blood pressure is one of the things that affect the human body system. An increase or decrease in blood pressure will affect homeostasis in the body. Many factors that can increase the risk or tendency of a person suffering from hypertension, including these individual characteristics such as age, weight, gender and ethnicity, genetic factors and environmental factors 
that include obesity, stress, salt consumption, smoking, consuming alcohol, and so on Ryadi, 2002 quoted from kurniawan, 2013).

The incidence of hypertension worldwide is about 972 million people or $26.4 \%$ of the earth's inhabitants have hypertension with a ratio of $26.6 \%$ men and $26.1 \%$ of women. This figure is likely to increase to $29.2 \%$ in 2025 from 972 million people with hypertension, 333 million are in developed countries and the remaining 639 million are in developing countries, including Indonesia (WHO, 2012 in Purwanto, 2012 quoted in Kurniawan 2014).

Hypertension is found with several risk factors that can cause high blood pressure, namely old age and the presence and presence of a history of high blood in the family. In addition, there are also so many causes of hypertension that causing hypertension is a disease with many sufferers even referred to as the silent diseasae (Cold-blooded Killer) (Palmer, 2007 quoted in Hairitama, Rini, et al, 2011). Sugiharto et al (2003), the incidence of hypertension is directly proportional to the increase in age. Arterial blood vessels lose elasticity or flexibility with age, most people's blood pressure increases when the age of 50-60 years and above.

In the concept of nursing, the reduction of blood pressure in hypertension can use management with the application of non-pharmacologists, one of which is deep breath relaxation techniques. Deep breath relaxation technique is one form of stress management in an effort to make lifestyle modifications. Appropriate (non-pharmacological) relaxation techniques are progressive muscle relaxation, autogenic exercise, breathing and visualization. Deep breath relaxation technique is one of the relaxation therapies that can make the body become calmer and harmonious, and able to empower the body to overcome the disorder that attacks it (Schwickert, 2006 in Putra, 2013).

Based on previous research by Elrita Tawang, 2013 on the influence of deep breath relaxation techniques on changes in blood pressure in people with moderate-severe hypertension showed that deep breath relaxation techniques can lower blood pressure in people with moderate-severe hypertension (Tawang E, 2013). This research is supported by Heryanto (2004), which diaphragmatic breathing until now became an easy method of relaxation in its implementation. Relaxation therapy diaphragmatic breathing technique is very good to be done every day by people with high blood pressure, in order to help the relaxation of the body's muscles, especially blood vessel muscles so as to maintain the elasticity of arterial blood vessels so that it can help lower blood pressure (Evelyn, 2011 quoted in Hastuti, Insiyah, 2015).

According to Audah (2011) breathing in a good way and control can provide relaxation and reduce stress. Deep breathing exercises are a form of non-pharmacological therapy, in which case nurses teach clients how to do deep breathing, slow breathing (holding inspiration to the maximum) and how to exhale slowly, in addition to lowering the intensity of pain can also increase pulmonary ventilation and increase blood oxygenation (Niken, 2010 in Putra 2013). Non-pharmacological management of deep breath relaxation therapy to lower blood pressure in people with hypertension was chosen because deep breath relaxation therapy can be done independently, relatively easy to do than other nonpharmacological therapies, does not take long for therapy and is able to reduce the adverse effects of pharmacological therapy for people with hypertension (Suwardianto, 2011 in Putra, 2013).
Based on data obtained from the Social Home Tresna Werdha Gau Mabaji Gowa Regency in 2016, there are 97 elderly people, namely the number of men 34 people or $(35 \%)$ and women 63 people or $(65 \%)$, who suffer from hypertension is 24 people or $(25 \%)$. According to nurses at the home, there has never been a deep breathing technique in the elderly that is specific to hypertension

\section{Material and Method}

This study uses one-group pretest-posttest design research. This design is a Pre experimental study in which researchers give treatment to a measured study group or in the next pretest after the treatment of the study group is measured or in the retest (Posttest).

This research will be conducted at Panti Trisna Werdha Gau Mabaji Gowa Regency.. Using purposive sampling is a sample taken from elderly respondents who meet the criteria that have been determined by researchers with inclusion criteria and exclusion criteria.

Primary data is taken and collected using questionnaires that have been available to obtain the general identity of the patient, and make observations based on Deep Breathing or deep breath relaxation techniques carried out in this case observation of deep breathing in the intervention group.

\section{Result and Discussion}

In this discussion, researchers will discuss the effectiveness of Deep Breathing against blood pressure reduction in elderly people who experience hypertension in tresna werdha gau mabaji in Gowa district.

1. Effect of decreased blood pressure day 1 psystolic with day 9 post systolic and pre day 1 diastolic with day 9 diastolic.

The results of the data analysis obtained the average value of systolic blood pressure pre-day 1 is 148.46 with a standard deviation of 6,887 . The average post-day blood pressure of 9 is 136.15 with a standard deviation of 6,504. After the statistical test obtained the value of $\mathrm{p}$ value $=0.000<$ $\alpha=0.05$ which means there is an effect of giving Deep Breathing to reduce blood pressure.

The average pre-day diastolic blood pressure was 89.23 with a standard deviation of 11.875 . The average post-day diastolic blood pressure was 82.31 with a standard deviation of 9,268 . After the statistical test obtained a value of $p$ value $=0.108>\alpha=0.05$ which means there is no effect of giving Deep Breathing to the decrease in blood pressure.

Ardiansyah (2012) stated that in general hypertension is high blood pressure that is abnormal and a person is considered to have hypertension if his blood pressure exceeds 140/90 $\mathrm{mmHg}$.

Brunner \& Suddarth (2002) states that the pathophysiology of hypertension occurs at the same time where the sympathizer nervous system stimulates blood vessels as an emotional excitatory response, the adrenal glands are also aroused, resulting in additional vaso compression activity. The medulla adrenal secretes epinephrine, which causes vasoconstriction. The adrenal context secretes cortisol and other steroids, which can strengthen the response of blood vessel vasoconstrictors. Vasoconstrictors stimulate the formation of angiotensin I which is then converted into angiotensin II, a powerful vasoconstrictor, which in turn stimulates the secretion of aldosterone by the adrenal cortex. This hormone causes retention of sodium and water by the renal tubules, causing an increase in intravascular volume. All of these factors tend to trigger hypertension. 
In line with Joseph's research, et al. (2005) conducted on 20 respondents with hypertension (ages $56.4 \pm 1.9$ years and above) intervened by normal breathing and slow breathing ( $6 \mathrm{x} /$ minute) and fast (15x / minute). Slow deep breathing can lower systolic and diastolic blood pressure in hypertensive patients (from $147.7 \pm 3.7 \mathrm{mmHg}$ to $141 \pm 4 \mathrm{mmHg}, \mathrm{p}<0.05$ and from $82.7 \pm 3 \mathrm{mmHg}$ to $77.8 \pm 3.7 \mathrm{mmHg}, \mathrm{p}<0.01$ ).

Joseph, et al. (2005) stated that Deep breathing has an effect on modulation of the cardiovascular system. Deep breathing has the effect of increasing the fluctuations of $\mathrm{RR}$ (rate of respiration) intervals. Fluctuations in increased RR intervals (relative to changes in blood pressure) have an impact on the increased effectiveness of bare reflex and may contribute to a decrease in blood pressure. Deep breathing also decreases sympathetic activity by increasing central inhibitory rhythms which eventually impacts the reduction in blood pressure when bare reflexes are activated. Deep breathing also affects the increase in tidal volume so that it activates the Vuling-Breuer reflex which has an impact on decreasing the activity of the flex and ultimately increasing the sensitivity of bare reflex. This mechanism can decrease sympathetic activity and blood pressure.

Based on the theory and research above I as a researcher agree that the provision of deep breathing relaxation techniques in people with hypertension, especially those in accordance with research in the elderly is very effective for lowering blood pressure.

According to Sunanto (2009) Hypertension is a condition in which a person experiences an increase in blood pressure above normal for a long period of time. If measured with a blood pressure test the results of blood pressure measurements show 140/80 mmHg. According to WHO (2012) in Porwanto (2012) hypertension is a public health problem in the world and is closely related to people's lifestyle patterns. Until now hypertension still remains a problem because of several things, including the increasing prevalence of hypertension, there are still many hypertensive patients who have not received treatment or who have been treated but their blood pressure has not reached the target, as well as the presence of accompanying diseases and complications in the form of target organ damage, especially in the heart and blood vessels that worsen the prognosis of hypertensive patients.

Ramdhani (2014) stated that relaxation of the deep breath is one of the self-management techniques based on the workings of the sympathetic and parasympathetic nervous system. Relaxation techniques are increasingly being done because they are proven to be effective in reducing tension and anxiety, and can lower blood pressure in people with hypertension. Diaphragmatic breathing until now has been an easy method of relaxation in its implementation. Deep breath relaxation technique therapy is very good to be done every day by people with hypertension, in order to help the body, especially the blood vessels, so as to maintain the elasticity of elastic blood vessels.

The results of research from Hastuti and Insiyah (2015) showed that. Blood pressure in hypertensive patients in Bendosari Health Center sukoharjo regency before deep breathing therapy is an average systolic blood pressure of $177.33 \mathrm{~mm} \mathrm{hg}$ and diastole average $95.87 \mathrm{~mm} \mathrm{hg}$. Blood pressure in hypertensive patients in Bendosari Health Center sukoharjo regency after deep breathing therapy is an average systolic blood pressure of $173.20 \mathrm{~mm}$ hg and diastole average $90.57 \mathrm{~mm} \mathrm{hg}$. There is an effect of deep breathing techniques on the reduction of blood pressure in hypertensive patients in Bendosari Health Center sukoharjo regency. The advice in this study is for health workers, especially nurses, to intervene in nursing, namely deep breathing therapy to decrease blood pressure in hypertensive patients.

Based on research and theory above as a researcher I agree that deep breathing relaxation techniques given to the elderly who have hypertension will be very effective to lower blood pressure. And also deep breath relaxation techniques include one of the best non-pharmacological treatments for the elderly and not difficult to do even elderly people who are already unable to walk or get out of bed.

\section{Proof of Hypothesis}

Based on the results of the data analysis, the average value of systolic blood pressure pre-day 1 is 148.46 with a standard deviation of 6,887 . The average post-day blood pressure of 9 is 136.15 with a standard deviation of 6,504. After the statistical test obtained the value of $\mathrm{p}$ value $=0.000<$ $\alpha=0.05$ which means there is an effect of giving Deep Breathing to reduce blood pressure.

The average pre-day diastolic blood pressure was 89.23 with a standard deviation of 11.875 . The average post-day diastolic blood pressure was 82.31 with a standard deviation of 9,268 . After the statistical test obtained a value of $p$ value $=0.108>\alpha=0.05$ which means there is no effect of giving Deep Breathing to the decrease in blood pressure.

The results of this study are in line with research conducted by Werdyastri et al (2014) that the decrease in blood pressure before and after the administration of deep breathing therapy in hypertensive patients at Tugurejo Hospital Semarang in March-April 2014 obtained blood pressure results before the administration of deep breathing (Deep Breathing) $170 \mathrm{mmHg}$, after the administration of deep breathing (Deep Breathing) obtained blood pressure $161 \mathrm{mmHg}$, while in diastolic blood pressure also obtained before the administration of deep breathing relaxation (Deep breathing) $96 \mathrm{mmHg}$, after the administration of deep breathing relaxation (Deep Breathing) obtained blood pressure $89 \mathrm{mmHg}$.

Researchers assume that after the act of giving deep breathing relaxation techniques on day 1 to day 9 , it can be known the effectiveness of deep breathing against the decreased blood pressure in elderly people who experience hypertension in tresna werdha gau mabaji gowa regency. This can be seen in the administration of deep breathing techniques on the first day to day 9 .

Thus it is known that deep breath relaxation techniques are effective for lowering blood pressure in the elderly. According to the assumption of researchers with relaxation techniques that are easy to do and without any side effects for the elderly, it is very important to apply in everyday life and can be done alone by respondents to lower blood pressure because with this relaxation technique helps the body to stay relaxed, can supply exigent with the levels needed by the body and help relieve the work of the heart, and keep the blood vessels in order.

\section{Conclusion}

After the study conducted with the title "Effectiveness of Cultural Deep Breathing Against Blood Pressure Reduction In Elderly Who Have Hypertension In Panti Tersna Werdha Gau Mabaji Gowa Regency" it can be concluded that the known average systolic blood pressure pre-day 1 is 148.46 with a standard deviation of 6,887 . The average post-day blood pressure of 9 is 136.15 with a standard deviation of 6,504. After the statistical test obtained the value of $p$ value $=0.000<\alpha=0.05$ which means there is an effect of giving Deep Breathing to reduce blood pressure. 
The average pre-day diastolic blood pressure is 89.23 with a standard deviation of 11,875 . The average post-day diastolic blood pressure was 82.31 with a standard deviation of 9,268 . After the statistical test obtained a value of $p$ value $=0.108>\alpha=0.05$ which means there is no effect of giving Deep Breathing to decrease blood pressure.

\section{References}

1. Azizah, M. Lilik. (2011). Keperawatan Lanjut Usia. Graha Ilmu. Yogyakarta

2. Bandiyah, Siti. (2009). Lanjut Usia dan Keperawtan Gerontik. Medical Book. Yoyakarta

3. Hart, T.J. Dkk. (2010) Tanya Jawab Seputar Tekanan Darah Tinggi. Edisi 2. ARCAN. Jakarta

4. Kluwer. W, Wilkins. Williams. Lippincott. (2012). Kapita Selekta Penyakit Dengan Implikasi Keperawatan. Diterjemahkan Widiarti. Dwi. Dkk. Penerbit Buku Kedokteran. EGC. Jakarta

5. Palmer. A, Williams. B. (2007). Tekanan Darah Tinggi. Diterjemahkan Astikawati. R, Safitri. A. Penerbit Erlangga. Jakarta

6. Mayer, Welas, Kowalak. (2012). Buku Ajar Patofisiologi. Penerbit Buku Kedokteran. EGC. Jakarta

7. Hidayat. Alimul. Aziz, A. (2007). Riset Keperawatan Dan Teknik Penulisan Ilmiah. Penerbit Salemba Medika. Jakarta

8. Maryam, S. Fatma. Mia. Dkk. (2010). Asuhan Keperawatan Pada Lansia. CV. Trans Info Media. Jak-Tim
9. Nuraini. B. (2015). Risk Factors Of Hypertension. Universitas Lampung

10. Wisnu, D. Wardani (2015). Pengaruh Teknik Relaksasi Napas Dalam Sebagai Terapi Tambahan Terhadap Penurunan Tekanan Darah Pada Pasien Hipertensi Tingkat 1. Univeritas Negeri Semarang

11. Ervan,K. Putra. (2013). Pengaruh Latihan Napas Dalam Terhadap Penuruna Tekanan DarahPada Penderita Hipertensi Diwilayah Kecamatan Karas Kabupaten Magetan. Universitas Muhammadiyah Surakarta

12. Sulastri, Dwi. (2015). Pengaruh Senam Lansia Terhadap Penurunan Tekanan Darah Pada Lansia Hipertensi Di Puskesmas Kalijambe Srage. STIKes Kusuma Husada Surakarta

13. Kurniawan, P. Andi.(2014).Stikes Kusuma Husada Surakarta

14. Erlita, Dkk. (2013). Pengaruh Teknik Relaksasi Napas Dalam Terhadap penurunan Tekanan Darah Pada Lansia Hipertensi Sedang Hingga Berat Di Ruang Irina C Blu Prof. Dr. DR. D. Kandou Manado \& Bitung. http;//scholar.Google.com/ Di akses 02 mei 2016

15. Anggriani, A.D, A. Waren, E. Situmorang, S.S, Siahaan, 2009, Faktor-faktor yang berhubungan dengan kejadian Hipertensi Pada Pasien yang Berobat di Poloklinik Dewasa Puskesmas Banginang Periode Januari sampai juni 2008 Di akses pada 02 mei 2016.
This work is licensed under Creative Commons Attribution 4.0 License

To Submit Your Article Click Here: Submit Manuscript

DOI:10.31579/2688-7517/033
Ready to submit your research? Choose Auctores and benefit from:

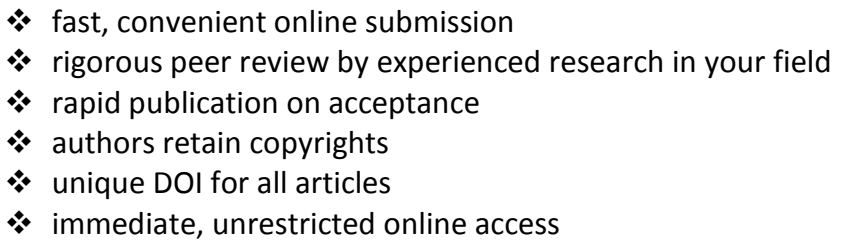

At Auctores, research is always in progress.

Learn more https://auctoresonline.org/journals/addiction-research-andadolescent-behaviour 